Литература

1.Концепция государственной энергетической политики Украины на период до 2020 г. // Информационное приложение. 2001. - № 10. - 8 c.

2. Даффи Дж., Бекман У.А. Тепловые процессы с использованием солнечной энергии. - М.: Мир, $1977 .-420$ с.

3.Селихов Ю.А., Ведь В.Е., Бухкало С.И., Костин В.М. Конструкционные особенности увеличения эффективности работы гелиоустановок. Экотехнологии и ресурсосбережение. - Киев: Типография НАН Украины, № 3, 2004. - С. 70-75.

4. Полімерна композиція: пат. 72078 А Україна. №2003088001 ; заявл. 27.08.2003 ; опубл. 17.01.2005, Бюл. № 1. 110 с.

5. Геліоводонагрівник: пат. 75178 Україна. № 2004021010 ; заявл. 12.02.2004 ; опубл. 15.03.2006, Бюл.

№ 3,120 c.

6. Коцаренко В.О., Селіхов Ю.А., Горбунов К.О. Розрахунки в середовищі Ехсеl: навч. посіб. - Харків: Вид-во «Підручник НТУ «ХПІ»», 2011. - $272 \mathrm{c}$.

\title{
References
}

1. (2001) Contseptsiya gosudarstvennoy energetichkoy politiki Ukrainy na period do $2020 \mathrm{~g}$. Informatsionnoe priloghenie.10. 8 .

2. Daffi Dzh., Bekman U.A. (1977) Teplovye protsesy s ispolzovaniem solnechoy energii. Moskow Mir,. 420.

3. Selikhov Yu. A., Ved V.E., Bukhkalo S. I., Kostin V. M. (2004) Consruktsonnie osobennosti uvelicheniy efektivnosti raboti gelioustanovok. Ekotekhnologii i resursosberezhenie. Kiev: Tipografia NAN Ukrainy. 3. 70-75.

4. Polimerna compozitsiya: pat. № 72078 A Ukrainy. №2003088001 ; zayavl. 27.08.2003 ; opubl. 17.01.2005, Byul. № 1. 110

5. Geliovodonagrivnyk: pat. № 75178 Ukrainy. № 2004021010 ; zayavl. 12.02.2004 ; opubl. 15.03.2006,

Byul. № 3, $120 \mathrm{~s}$.

6. Kotsarenko V.O., Selikhov Yu. A., Gorbunov K.O. (2011) Rozrakhky v seredovyschi Excel: navch. Posib. - Kharkiv: Vyd-vo «Pidruchnyk NTY «KhPI», 272.

\section{ДОСЛІДЖЕННЯ ПРОЦЕСІВ КОМПОСТУВАННЯ ХАРЧОВОЇ СКЛАДОВОЇ ТВЕРДИХ МУНІЦИПАЛЬНИХ ВІДХОДІВ З ВИКОРИСТАННЯМ МІНЕРАЛЬНИХ ДОБАВОК}

\author{
Крусір Г.В., д.т.н., професор, Сагдєєва О.А., Чернишова О.О., асистент, Мадані М.М., к.Т.н., доцент, \\ Гаркович О.Л., к.б.н., доцент \\ Одеська національна академія харчових технологій, м. Одеса
}

\begin{abstract}
Анотація. Ефективне управління твердими муніципальними відходами є першочерговим завданням у сфері міжнародної та національної екологічної безпеки. В Украӥні воно фактично вирішується через зберігання сотень тисяч відходів на керованих та некерованих звалищах та полігонах.

Оскільки до 40\% твердих муніципальних відходів відноситься до органічних, щзо легко розкладаються (харчові відходи, відходи ринків, домогосподарств, міських зелених господарств, муніџипальної мережі харчування), вилучення цієї частини відходів зі звалищ за рахунок компостування суттєво зменшить навантаження на фактично розмішенні та потенційно заплановані звалищза.

Аеробне компостування є однією з найкращих найбільш доступних технологій для інтегрованої системи управління відходами за рахунок мінімізації антропогенного впливу на довкілля, відповідності новітнім вітчизняним та зарубіжним розробкам, економічної та практичної прийнятності технології.

Метою експериментального дослідження було вивчення можливості прискорення прочесу компостування харчової складової твердих муніципальних відходів за рахунок внесення мінеральних добавок для впровадження в якості природоохоронної технологї̈ на звалищах.

У статті представлено результати дослідження впливу мінеральної добавки на перебіг процесів компостування харчової складової твердих муніципальних відходів з метою його прискорення в мезофільному і термофільному температурних режимах з керованими параметрами. Для підвищення ефективності процесу компостування та порівняння особливостей перебігу процесів в якості мікробіологічного інокуляту використовували трунт, в якості мінеральної добавки - розчини мінеральних солей.

Показано, щзо мінеральний комплекс прискорює прочес компостування харчової складової твердих побутових відходів в 2,2 рази за термофільного режиму і в 1,4 рази за мезофільних умов проведення процесу компостування, щзо свідчить про ефективність його використання в процесах переробки твердих муніцииальних відходів з метою підвищення загального рівня екологічної безпеки.

Ключові слова: компостування; відходи; суміш, що компостується; мінеральна добавка; мезофільний і термофільний режими компостування
\end{abstract}




\title{
STUDY OF COMPOSTING PROCESSES OF MUNICIPAL SOLID WASTES' FOOD COMPONENTS WITH THE USE OF MINERAL ADDITIVES
}

\author{
Krusir G.V., Doctor of Tech. Sci., Sagdeeva O.A., Chernyshova O.O., assistant, \\ Madany M.M., PhD in Tech. Sci., associate prof., Garkovych O.L., PhD in Bio.Sci., associate prof.
}

\section{Odessa National Academy of Food Technologies}

\begin{abstract}
Efficient management of municipal solid waste is a top priority in the field of international and national environmental safety. In Ukraine, it is actually dealt with through the storage of hundreds of thousands of waste at managed and unmanaged landfills. Since up to $40 \%$ of municipal solid waste is classified as organic (food waste, market waste, households' waste, waste of municipal food network and urban green household), removing this part of waste from landfill by composting will substantially reduce the load on the actual placed and potentially planned landfill. Aerobic composting is one of the best available technologies for an integrated waste management system, minimizing anthropogenic environmental impact, complying with the latest domestic and foreign developments, economic and practical acceptance of technology.

The purpose of the pilot study was to study the possibility of accelerating the composting process of the municipal solid waste's food component through the using of mineral additives for the introduction as a conservation technology in landfills. The article presents the study results of the mineral additive's influence on the composting process of the solid municipal waste's food component in order to accelerate it in the mesophilic and thermophilic temperature regimes with controlled parameters. To improve the composting process and to compare the peculiarities of the processes the soil was used as microbiological inoculums and the mineral salts' solutes were used as a mineral additive.

It was shown that the mineral complex accelerates the composting process of the municipal solid waste's food component by 2.2 times for the thermophilic regime and by 1.4 times for the mesophilic conditions of composting process, that testifies to the efficiency of its use in the municipal solid waste' recycling processes in order to improve the overall level of environmental safety.
\end{abstract}

Keywords: composting; waste; composting mixture; mineral additive; mesophilic and thermophilic modes of composting

Вступ. Оцінка впливу на довкілля та визначення екологічних аспектів звалищ твердих муніципальних відходів $\epsilon$ актуальним завданням природоохоронної сфери в більшості країн світу. Безперечно, звалища відходів, облаштовані без сучасних інженерно-екологічних вимог, є потужними джерелами компонентів біосфери [1;2]. Харчові та рослинні відходи в складі твердих муніципальних відходів (до 40\%), які характеризуються найбільшим обсягом та здатністю до біохімічних реакцій, потребують розробки технологічних заходів щодо мінімізації їх кількості та впливу на навколишне середовище [3]. Найбільш екологічно доцільним методом переробки такого виду відходів $є$ компостування, яке відноситься до біотехнологічних методів утилізації, базується на природних процесах і тому є безпечним для живих організмів та довкілля [4-6].

Аналіз літературних джерел та формулювання мети досліджень. В країнах СС та у світі стрімко поширюється органічне виробництво як цілісна система раціонального природокористування, що стає основою застосування сучасних технологій компостування органічної сировини з отриманням якісного продукту переробки. Компостування, як природоохоронна технологія утилізації харчової складової твердих муніципальних відходів на звалищах, призводить до деструкції відходів за допомогою мікроорганізмів та отримання гігієнічно безпечної нетоксичної гумусоподібної речовини, яка з успіхом використовується, в першу чергу, як стимулятор відновлення грунтових екосистем, і в другу - як органічне добриво. Проте компостування характеризується відносно невисокою популярністю в порівнянні з іншими методами утилізації відходів через низку його недоліків, таких як довгий виробничий цикл та, іноді, одержання продукту нестабільної якості. Через це багато досліджень в галузі переробки твердих побутових відходів присвячено способам прискорення процесу компостування через розробку високоефективних апаратів компостування та зміну біотичних (вермикомпостування, використання спеціалізованих культур й співтовариств мікроорганізмів) або абіотичних (температура, $\mathrm{pH}$, аерація, вологість тощо) параметрів перебігу процесу [7; 8].

Пошук оптимального співвідношення біотичних та абіотичних параметрів залишається першочерговою задачею в технології компостування.

Серед сучасних дослідників процесу компостування як раціонального способу управління відходами інноваційними є праці М. В. Гаценка [9], М. К. Лінника [10], О. О. Ляшенка [11], В. В. Шацького [12], в яких багато уваги приділено питанням технології компостування, механізації приготування субстрату, оптимізації керованих параметрів перебігу процесу, оформленню буртів, складу субстрату та співвідношенню основних поживних речовин в ньому. Проте, поряд з питаннями прискорення процесу компостування як заходу зменшення органічних відходів, актуальним залишається утворення конкурентно-

Наукові праці, Том 82, випуск 1

Scientific Works, Volume 82, Issue 1 
спроможного органічного добрива, яке за еколого-економічними показниками здатне задовольняти потреби агропромислового комплексу країни.

Метою даного дослідження було вивчення можливості прискорення процесу компостування рослинних відходів за рахунок внесення мінеральних добавок. Передбачалося, що їх додавання до складу сировинного матеріалу приведе до активації мікробної активності на початкових стадіях процесу.

В ході даного досліджування повинно було виконати наступні завдання:

1) дослідити вплив мінеральних добавок на процеси, що відбуваються при компостуванні органічних відходів у мезофільному та термофільному режимах;

2) дослідити умови перебігу процесів компостування за основними абіотичними і біотичними показниками - за зміною температури, $\mathrm{pH}$ та чисельності мікроорганізмів в суміші, що компостується, витраті Карбону (емісії $\mathrm{CO}_{2}$ ) із реактора;

3) визначити зрілість компосту за індексом пророщування і співвідношення вмісту загального Карбону і Нітрогену в суміші, яка компостувалась.

Матеріали та методи досліджень. В якості сировини для компостування використовували суміш харчових (очистки картоплі, кабачків та моркви, листя капусти), сільськогосподарських (бур'ян) і садовопаркових (листяний опад) відходів у ваговому співвідношенні 1:1:1. Листяний опад використовували в якості наповнювача. Сировину подрібнювали до розмірів 10-15 мм, підсушували на повітрі протягом 2 годин і загружали в реактор. В якості добавок для підвищення ефективності процесу компостування та порівняння особливостей перебігу процесів використовували розчини мінеральних солей (нітрат кальцію, дигідрофосфат калію і сульфат магнію). Варто зазначити, що за результатами досліджень [13] структура мікробних комплексів $є$ невід'ємною складовою детальної характеристики грунтів, тому доцільно використовувати мікробні комплекси грунту в якості мікробіологічної добавки для компостування в природних умовах.

Експеримент проводили в трьох стаціонарних реакторах об'ємом 3 дм 3 примусовою аерацією протягом 6 тижнів. Умови проведення експерименту наведені в таблиці 1.

Таблиця 1

Умови проведення експерименту

\begin{tabular}{|c|c|c|c|}
\hline Номер реактора & Інокулят & Добавка & Температура навколишнього середовища, ${ }^{\circ} \mathrm{C}$ \\
\hline 1 & грунт & - & $18-20$ \\
\hline 2 & грунт & мінеральна & $18-20$ \\
\hline 3 & грунт & мінеральна & 55 \\
\hline
\end{tabular}

В кожний реактор вносили суміш, яка компостується (КС), в кількості 1,2 кг (2/3 об’єму) з вологістю біля $75 \%$, яка перемішувалась зі 100 г грунту (типовий для регіону чорнозем південний малогумусний) в якості інокуляту. В реактори 2 і 3 додатково вносили розчини мінеральних солей в кількості 150 г/кг сухої КС за вагового співвідношення $\mathrm{Ca}\left(\mathrm{NO}_{3}\right)_{2} * 4 \mathrm{H}_{2} \mathrm{O}: \mathrm{KH}_{2} \mathrm{PO}_{4}: \mathrm{MgSO}_{4} * 7 \mathrm{H}_{2} \mathrm{O}=4: 2: 1$

Реактори 1 і 2 були ізольовані від дії температури навколишнього середовища. Реактор 3 помістили в термостат зі встановленою температурою $55^{\circ} \mathrm{C}$ з метою термофільного компостування.

Компостування продовжувалось протягом 6 тижнів, при цьому суміш, яка компостувалась, кожного дня перемішували та зволожували для підтримання вологості на рівні біля 70-75 \%. Кожного тижня проводили відбір наважок масою біля 10 г для проведення аналізів.

Контроль параметрів процесу компостування здійснювали за зміною температури, рН та чисельності мікроорганізмів в суміші, що компостується, а також емісії $\mathrm{CO}_{2}$ із реактора. Зрілість компосту, який отримували, визначали за індексом пророщування і співвідношенням вмісту загального Карбону і Нітрогену в суміші, яка компостувалась.

Результати дослідження та їхнє обговорення. У літературі досить повно представлена інформація про біохімічні, мікробіологічні і інші аспекти процесу компостування органічних відходів, що утворюються в сільському і комунальному господарстві, харчовій промисловості та ін. Тому в подальшому необхідно було оцінити, чи впливає інокуляція компостних сумішей мінеральними добавками на процес компостування органічних відходів. В цілому, завершеність процесу компостування характеризується двома поняттями - «стабільність» і «зрілість» компосту, які, незважаючи на свої концептуальні відмінності, одночасно використовуються для визначення ступеню розкладання органічних речовин $(\mathrm{OP})$ під час процесу компостування. Були обрані параметри, що дозволяють оцінити як інтенсивність розкладання ОР (температура, вміст ОР, розчинного органічного Карбону (РОК) і амонійного азоту), так і його стабільність(респіраторна активність і целюлозолітична активність, чисельність бактерій і мікроміцетів) і зрілість (рН, фітотоксичність).

Результати досліджень зміни $\mathrm{pH}$ суміші, яка компостується, представлено на рис.1, зміни емісії $\mathrm{CO}_{2}$ із реакторів - на рис. 2

Початкове значення $\mathrm{pH}$ сировини було слабокислим, близьким до нейтрального $(6,3)$. У реакторах 3 мінеральною добавкою в термофільних умовах значення рН середовища спочатку змінювалось в слабо-

Наукові праці, Том 82, випуск 1 
кислому інтервалі $\mathrm{pH}$, потім середовище стало близьким до нейтрального, а в мезофільних - $\mathrm{pH}$ спочатку злегка підвищувалось до 7,6 од. $\mathrm{pH}$, потім знижувалось до 5,4 і далі $\mathrm{pH}$ середовища змінювалось на нейтральне. Кінцеве значення $\mathrm{pH}$ у всіх компостах було приблизно однаковим $(6,9-7,6)$, що свідчить про завершення процесу дозрівання компостної суміші. Значення рН середовища контрольного зразка на 6-й тиждень компостування складало 5,9 од. pH, що вказує на перебіг біохімічних процесів в ньому.

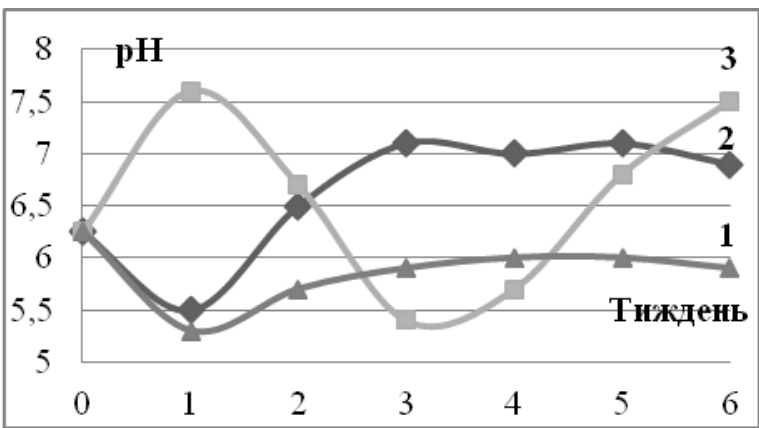

Рис. 1. Зміна рН суміші, яка компостусться, в реакторах $з$ мінеральною добавкоюв мезофільному (2) та термофільному режимах (3) в порівнянні з контрольним зразком (1).

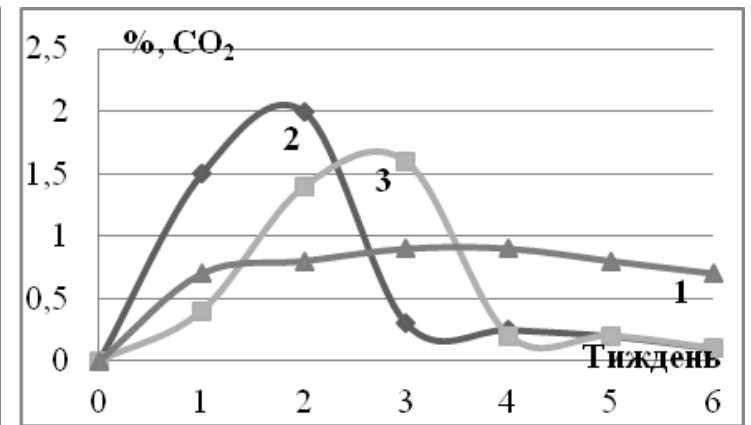

Рис. 2. Зміна емісії $\mathrm{CO}_{2}$ із реакторів протягом процесу компостування суміші $з$ мінеральною добавкою в мезофільному (2) та термофільному режимах (3) в порівнянні $з$ контрольним зразком (1), \% $\mathrm{CO}_{2}$.

Про активність мікроорганізмів можна судити за інтенсивністю їх дихання (споживання кисню або виділення вуглекислого газу). Представлені на рис. 2 залежності зміни концентрації $\mathrm{CO}_{2}$ в просторі реактора від тривалості процесу біодеструкції показово демонструють зміни активності колоній мікроорганізмів при компостуванні. Активність мікроорганізмів значно вища в реакторі, що знаходиться в термофільних умовах. В реакторах 2 і 3 найбільше значення активності припадає на період 3 другого по третій тиждень, що свідчить про те, що введення мінеральних добавок стимулює підвищення активності співтовариства мікроорганізмів на початкових стадіях компостування.

Характер залежності зміни кількості загального Карбону від тривалості компостування, який представлений на рис. 3, приблизно однаковий для всіх реакторів: в перші 4 тижні мінералізується більша кількість органічної речовини (близько 20\%), потім Карбон споживається незначно (3-4\%). Максимальні швидкості деструкції органічних речовин у всіх реакторах спостерігалися після другого тижня. Сумарні втрати загального Карбону були більш значні в реакторі 3 (22\%), ніж в реакторі 2 (близько 21\%). Таким чином, загальні втрати і швидкість втрат загального Карбону більш виражена при термофільному компостуванні, що свідчить про інтенсивність розкладання органічної речовини саме в цьому режимі.



Рис. 3. Зміна швидкості втрат загального Карбону в суміші, яка компостується, в реакторах 3 мінеральною добавкою в мезофільному (2) та термофільному режимах (3), в порівнянні 3 контрольним зразком (1), \% /тиждень.

Характер зміни вмісту загального Нітрогену в суміші, що компостується, практично ідентичний для всіх реакторів (рис. 4). В реактори 2 і 3 вносилася мінеральна добавка, яка містить нітрат-іони, тому вміст Нітрогену в масі, що компостується, після першого тижня вищий, ніж у вихідній сировині. Макси- 
мальні швидкості втрати Нітрогену у всіх реакторах спостерігалися після третього тижня, причому в реакторі, що функціонує за термофільних умов вона була більш значною і склала 4,5 г/кг КС за тиждень.



Рис. 4. Зміна швидкості втрат загального Нітрогену в суміші, яка компостується, в реакторах 3 мінеральною добавкою в мезофільному (2) та термофільному режимах (3) в порівнянні $з$ контрольним зразком (1), г/кг за тиждень.

Сумарні втрати Нітрогену в реакторі 3 виявилися найбільшими (близько 16 г/кг сухої маси, яка компостується), що свідчить при збільшення втрат Нітрогену при термофільному компостуванні в разі внесення мінеральної добавки. Однак вміст загального Нітрогену в реакторах 2 і 3 в кінці компостування склав 31 і 29 г/кг сухої маси, яка компостується, відповідно, що на 35-40\% більше, ніж в контрольному зразку.

Зрілість компосту оцінюється за масовим співвідношенням в ньому загального Карбону і загального Нітрогену $(\mathrm{C} / \mathrm{N})$. Згідно $з$ міжнародними стандартами якісний компост повинен мати C/N нижче 25 . У табл. 2 наведено залежність зміни $\mathrm{C} / \mathrm{N}$ від тривалості компостування. Відношення $\mathrm{C} / \mathrm{N}$ практично не залежить від температури, але помітно знижується при внесенні Нітрогену з мінеральною добавкою.

Таблиця 2

Зміни відношення загального Карбону до загального Нітрогену, C/N

\begin{tabular}{|c|c|c|c|c|c|c|c|}
\hline \multirow{2}{*}{ Реактор } & \multicolumn{7}{|c|}{ Час, тижні } \\
\cline { 2 - 9 } & 0 & 1 & 2 & 3 & 4 & 5 & 6 \\
\hline 1 & 36,0 & 35,5 & 35,0 & 34,5 & 33,0 & 32,2 & 29,5 \\
\hline 2 & 36,0 & 33,0 & 31,5 & 30,4 & 28,5 & 26,3 & 22,3 \\
\hline 3 & 36,0 & 32,2 & 30,7 & 29,8 & 26,7 & 23,3 & 21,5 \\
\hline
\end{tabular}

Кінцеве співвідношення C/N у всіх одержаних компостах менше, ніж 25, що свідчить про скорочення дозрівання компосту при внесенні мінеральної добавки приблизно вдвічі, враховуючи швидкість його зміни.

Результати дослідження свідчать про те, що індекс пророщування насіння редису поступово знижується зі збільшенням тривалості компостування (рис. 5). Компост з індексом пророщування менше, ніж $80 \%$, вважається фітотоксичним, більше, ніж $80 \%,-$ зрілим.



Рис. 5. Зміни індексу пророщування в процесі компостування в КС в реакторах 3 мінеральною добавкою в мезофільному (2) та термофільному режимах (3) в порівнянні 3 контрольним зразком (1), \%

Після 6 тижнів компостування компости в реакторах 2 і 3 характеризуються індексом пророщування більше, ніж 100 \%, що свідчить про те, що компости не тільки не містять фітотоксинів, але і проявляють 
стимулюючу дію на процес пророщування. Експериментальні дані дослідження дозволяють зробити висновок, що дозрівання компосту в термофільних умовах завершується швидше, ніж в мезофільних, а тривалість дозрівання компосту при внесенні мінеральної добавки прискорюється в 2,2 рази за термофільних умов та в 1,4 рази - за мезофільних.

Висновки. Таким чином, результати проведених досліджень дозволяють зробити висновок про доцільність компостування рослинних відходів з мінеральною добавкою як у випадку термофільного, так і у випадку мезофільного компостування.

Період дозрівання компосту при використанні мінеральної добавки становить 6 тижнів. Показано, що мінеральний комплекс прискорює процес компостування органічної складової твердих побутових відходів приблизно вдвічі як за термофільного режиму, так і за мезофільних умов проведення процесу компостування, що свідчить про ефективність його використання в процесах переробки твердих побутових відходів з метою підвищення загального рівня екологічної безпеки.

\section{Література}

1. Gworek B., Dmuchowski W., Koda E., Marecka M., Baczewska A., Bragoszewska P., Sieczka A., Osiński P. Impact of the Municipal Solid Waste Łubna Landfill on Environmental Pollution by Heavy Metals. // Water. 2016. T. 8 (10). 470. DOI: 10.3390/w8100470

2. Дзяд О. В., Цвєтаєва К. В. Ресайклінг муніципальних відходів у промислово розвинених країнах світу: порівняльний аспект // Вісник Дніпропетровського університету. 2015. № 7. С. 3-12 DOI: 10.15421/181501

3. Шмарин С. Л., Алексеевец И. Л., Филозоф Р. С., Ремез Н. С., Денафас Г. Содержание биоразлагаемых компонентов в составе твердых бытовых отходов в Украине // Экология и промышленность № 1. 2014. № 1. С. 79-83

4. Adani F., Tambone F., Gotti A. Biostabilization of municipal solid waste// Waste Management. 2004. T. 24, № 8. C. 775-783. DOI: 10.1016/j.wasman.2004.03.007

5. Jouraiphy A. Chemical and spectroscopic analysis of organic matter transformation composting of sewage sludge and green plant waste // International biodeterioration and biodegradation. 2005. № 56. C. 101-108. DOI: 10.1016/j.ibiod.2005.06.002

6. Yong Xiao, Guang-Ming Zeng, Zhao-Hui Yang. Continuous thermophilic composting (CTC) for rapid biodegradation and maturation of organic municipal solid waste // Bioresource Technology. 2009. T. 100, № 20. C. 4807-4813. DOI: 10.1016/j.biortech.2009.05.013

7. Пат. на корисну модель №100991 Україна. С02F 7/00 Спосіб компостування органічних відходів / Шацький В.В., Поволоцький А.А.; власник Запорізький НДЦ з механізації тваринництва ННЦ "Інститут механізації та електрифікації сільського господарства" НААН України. - u 2014 13758; Заявл. 22.12.2014; опубл. 25.08.2015. Бюл. № 16.

8. Kulcu R.,Yaldiz O. Determination of aeration rate and kinetics of composting some agricultural wastes // Bioresource Technology. 2004. Vol. 93. P. 49-57. doi: 10.1016/j.biortech.2003.10.007.

9. Гаценко М. В. Компостування органічної речовини. Мікробіологічні аспекти // Сільськогосподарська мікробіологія. 2014.№ 19(1). C. 11-20. http://nbuv.gov.ua/UJRN/smik_2014_19_3. $244 \mathrm{c}$.

10. Лінник М. Г., Семчук М. М. Технології і технічні засоби виробництва та використання органічних добрив. Ніжин, 2012.

11. Ляшенко О. О., Мовсесов Г. Є. Технологія та устаткування прискореного компостування органічних відходів // Сотрудничество для решения проблемы отходов: матеріали III Міжнар. конф., 7-8 лют. 2006 р. С. $88-89$. https://www.waste.com.ua/cooperation/2006/theses/lyashenko.html.

12. Шацький В. В., Поволоцький А. А. Основні вимоги до процесу та біотехнічної системи компостування органічної сировини // Вісник Харківського національного технічного університету сільського господарства імені Петра Василенка. 2015. № 157. С. 140-146. http://nbuv.gov.ua/UJRN/Vkhdtusg_2015_157_26.

13. Fierer N., Jackson R.B. The diversity and biogeography of soil bacterial communities // PNAS. 2006. T. 103, № 3. C. 626-631. https://www.ncbi.nlm.nih.gov/pubmed/16407148

\section{References}

1. Gworek, B., Dmuchowski, W., Koda, E., Marecka, M., Baczewska, A., Brągoszewska, P., Sieczka, A. Osiński, P. (2016). Impact of the Municipal Solid Waste Łubna Landfill on Environmental Pollution by Heavy Metals. Water, 8 (10), 470. doi: 10.3390/w8100470

2. Dzjad, O. V., Cvjetajeva, K. V. (2015). Resajkling municypal'nyh vidhodiv u promyslovo rozvynenyh krai'nah svitu: porivnjal'nyj aspekt, Visnyk Dnipropetrovs'kogo universytetu, no 7, pp. 3-12 (in Ukrainian).

DOI: $10.15421 / 181501$

3. Shmarin, S. L., Alekseevec, I. L., Filozof, R. S., Remez, N. S., Denafas, G. (2014) Soderzhanie biorazlagaemyh komponentov v sostave tverdyh bytovyh othodov v Ukraine, Ekologija i promyshlennost', no. 1, pp. 79-83 (in Russian).

4. Adani, F., Tambone, F., Gotti, A. (2004). Biostabilization of municipal solid waste. Waste Management. Vol. 24, no. 8, pp. 775783.

DOI: 10.1016/j.wasman.2004.03.007

5. Jouraiphy, A. (2005). Chemical and spectroscopic analysis of organic matter transformation composting of sewage sludge and green plant waste. International biodeterioration and biodegradation, no. 56, pp. 101-108.

DOI: 10.1016/j.ibiod.2005.06.002

6. Yong, X., Guang-Ming, Z., Zhao-Hui, Y. (2009). Continuous thermophilic composting (CTC) for rapid biodegradation and maturation of organic municipal solid waste. Bioresource Technology, Vol. 100, no. 20, pp. 4807-4813.

DOI: 10.1016/j.biortech.2009.05.013

Shatsky, V.V.,\& Povolotsky, A.A. (2015). Method of Composting of Organic Waste.Patent for Utility Model No. 100991 Ukraine. C02F 7/00. u 2014 13758. Declared 22.12.2014; Published August 25, 2015, Bull No. 16

8. Kulcu, R.,\&Yaldiz, O. (2004). Determination of aeration rate and kinetics of composting some agricultural wastes. Bioresource Technology, 93, 49-57. doi: 10.1016/j.biortech.2003.10.007.

9. Hatsenko, M. V. (2014). Kompostuvannya orhanichnoyi rechovyny. Mikrobiolohichni aspekty.Sil's'kohospodars'ka mikrobiolohiya, 19(1), 11-20. http://nbuv.gov.ua/UJRN/smik_2014_19_3.

10. Linnyk, M. H., \& Semchuk, M. M. (2012).Tekhnolohiyi i tekhnichni zasoby vyrobnytstva ta vykorystannya orhanichnykh dobryv. Nizhyn, 244 s.

11. Lyashenko, O. O., \& Movsesov, H. YE. (2006). Tekhnolohiya ta ustatkuvannya pryskorenoho kompostuvannya orhanichnykh vidkhodiv. Sotrudnychestvo dlya reshenyya problemy otkhodov: materialy III Mizhnar. konf., 7-8 lyut. r. S. 88-89. https://www.waste.com.ua/cooperation/2006/theses/lyashenko.html.

Наукові праці, Том 82, випуск 1

Scientific Works, Volume 82, Issue 1 
12. Shats'kyy, V. V., \& Povolots'kyy, A. A. (2015). Osnovni vymohy do protsesu ta biotekhnichnoyi systemy kompostuvannya orhanichnoyi syrovyny. Visnyk Kharkivs'koho natsional'noho tekhnichnoho universytetu sil's'koho hospodarstva imeni Petra Vasylenka,157, 140-146. http://nbuv.gov.ua/UJRN/Vkhdtusg_2015_157_26.

13. Fierer N, Jackson RB. The diversity and biogeography of soil bacterial communities. PNAS. 2006 Jan 17; 103(3): 626-31 https://www.ncbi.nlm.nih.gov/pubmed/16407148

Отримано в редакцію 18.04.2018

Прийнято до друку 30.06.2018
Received 18.04.2018

Approved 30.06.2018

УДК 62229.316.002.51/52:665.3

DOI: http://dx.doi.org/10.15673/swonaft.v82i1.1014

\title{
ФОРМУВАННЯ ТЕХНОЛОГІЇ ОЧИСТКИ РОСЛИННОЇ ОЛІї В УМОВАХ МІНІ-ЦЕХІВ
}

\author{
Осадчук П. І. кандидат технічних наук, доцент \\ Дударєв I. I. кандидат технічних наук, доцент \\ Одеський державний аграрний університет, м. Одеса
}

\begin{abstract}
Анотація: Створено комплекс технічних засобів, щчо включає обладнання $і$ блоки пресування насіння, адсорбентної рафінації, гідратаиії $і$ коагуляиії, центрифугування $і$ дезодорації, очищення $і$ мікрофільтрачії олії. Конструкиї технічних засобів дозволяють компонувати окремі складові частини поблочно (модульно), враховуючи умови їх розміщення у мало контурних цехах. У технологічному процесі, за необхідності використовується ультразвуковий кавітатор для зниження кислотності олії. Сформований за ичим принципом комплекс забезпечує одержання екологічно чистої рослинної олії за безвідхідною технологією, щзо актуальна для фермерських господарств. Олія такої якості відноситься до категорії кашерних продуктів.
\end{abstract}

Ключові слова: агровиробництво, олія рослинна, технологія, обладнання, показники якості.

\section{FORMATION OF PLANE OLIVE CLEANING TECHNOLOGIES IN MINI-SHOPS CONDITIONS}

\author{
Osadchuk P.I., PhD, associate professor \\ Dudarev I.I., PhD, associate professor \\ Odessa state agricultural university, Odessa, Ukraine
}

\begin{abstract}
To obtain high-quality edible oils, these should be as much as possible cleaned from concomitant substances, mechanical impurities, phosphatides, waxes, soap and hydrophobic fractions. This process can be realized on the basis of physical methods developed by us with the help of special centrifugal devices, ceramic microfilters, hydration means for purifying phosphatidic concentrate with subsequent belting filtration of monodibasic unsaturated acids A complex of technical means was developed, including equipment and blocks for pressing the seed, adsorbent refinement, hydration and coagulation, centrifugation and deodorization, cleaning and microfiltration of oils. Structures of technical means allow to compose separate components of a unit (modular), taking into account the conditions of their placement in small contour workshops. In the technological process, if necessary, an ultrasonic cavitator is used to reduce the acidity of the oil. The complex formed on this principle ensures the production of ecologically pure vegetable oil in the non-waste technology and in the conditions of the farms. Oil of this quality belongs to the category of casserole products.The technological process involves pressing the seeds, then feeding to a centrifuge for purification from mechanical impurities, for removing water and lightly flowing fractions into a vacuum chamber and microfiltration and lighting in the supercleaner unit, an ultrasonic cavitator is used to reduce the acidity of the oil. The vegetable oil retains its organoleptic qualities and the nutritional value of the product. Such an effect is achieved by the use of only the production of oils, physical and mechanical processes, without chemical treatment. The technology is implemented by a compact small-scale technical complex, executed in a modular-block type, which is easy to control.
\end{abstract}

Key words: agricultural production, vegetable oil, technology, equipment, quality indices.

Вступ. На сьогодні в міні-цехах агровиробництва і фермерських господарств широко розповсюджена спрощена технологія отримання соняшникової олії, що базується на простому і не дорогому обладнанні. Однак, ця технологія не включає в себе наступну очистку олії, яка відповідала би діючим стандартам якості продукту щодо вмісту механічних домішок та канцерогенних речовин.

Актуальність. Левова частка всіх показників якості олії припадає на процес очищення. Отож чим краще очищена олія - тим вона якісніша, в певній мірі. Отриманні рослинні олії містять різні механічні домішки, супутні речовини, білкові, слизисті, ароматичні речовини, пігменти, можуть містити продукти розпаду жирів (вільні жирні кислоти і продукти їх окислення) та інші. Багато з них забезпечують специ-

Наукові праці, Том 82, випуск 1 Scientific Works, Volume 82, Issue 1 